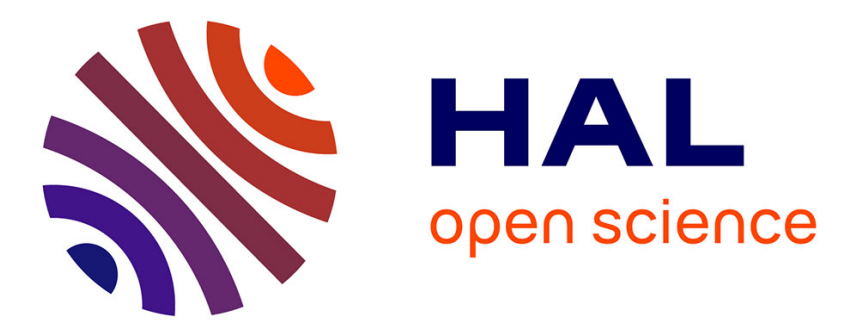

\title{
Near-field optical imaging of plasmonic waveguides using heterodyne optical feedback on Er doped DFB fibre laser
}

M Roblin, Sébastien Girard, H Gilles, M Laroche, J. Cardin, C Dufour

\section{To cite this version:}

M Roblin, Sébastien Girard, H Gilles, M Laroche, J. Cardin, et al.. Near-field optical imaging of plasmonic waveguides using heterodyne optical feedback on Er doped DFB fibre laser. The European Conference on Lasers and Electro-Optics (CLEO_Europe), May 2011, Munich, Germany. pp.CK3_4, 10.1109/CLEOE.2011.5943223 . hal-01139809

\section{HAL Id: hal-01139809 \\ https://hal.science/hal-01139809}

Submitted on 9 Apr 2015

HAL is a multi-disciplinary open access archive for the deposit and dissemination of scientific research documents, whether they are published or not. The documents may come from teaching and research institutions in France or abroad, or from public or private research centers.
L'archive ouverte pluridisciplinaire HAL, est destinée au dépôt et à la diffusion de documents scientifiques de niveau recherche, publiés ou non, émanant des établissements d'enseignement et de recherche français ou étrangers, des laboratoires publics ou privés. 


\title{
Near-field optical imaging of plasmonic waveguides using heterodyne optical feedback on Er doped DFB fibre laser
}

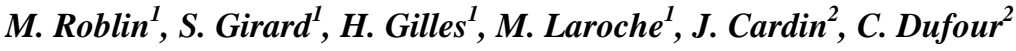 \\ ${ }^{1}$ LIOA Lasers, Instrumentation Optique et Applications, \\ ${ }^{2}$ NIMPH Nanostructures Intégrées pour la Microélectronique et la Photonique, \\ Centre de recherche sur les Ions, les MAtériaux et la Photonique (CIMAP), \\ ENSICAEN, CNRS, CEA/IRAMIS, Université de Caen, 14050 Caen, France
}

Laser Feedback Interferometry (LFI) has been already investigated as an efficient tool for near-field optical imaging [1,2]. In this approach, the optical near-field collected by a micro tip on the top of the sample is frequency shifted before being re-injected in the single-frequency solid-state laser used to illuminate the device. Adjusting the frequency shift close to the relaxation oscillations of the class B laser leads to a strong amplification (up to $+60 \mathrm{~dB}$ ) due to the frequency transfer function of the optical oscillator. In the case of Near field Scanning Optical Microscopy (NSOM), it allows amplitude and phase detection of the optical near field with quantum-noise limited signal-to-noise ratio even in the infrared domain where thermal noise could become an issue. The technique is currently applied to the characterization of the losses in plasmonic optical waveguides. A series of thin gold strips with thicknesses in the $15-25 \mathrm{~nm}$ range and widths between 2 to $10 \mu \mathrm{m}$ were processed by optical lithography on silica substrate. Using the Kretsmann-Raether (KR) configuration [4], the incident light beam was efficiently coupled to a Surface Plasmon-Polariton (SPP) guided mode on the top of a selected gold strip (figure $1 \mathrm{a}$ ). A single-frequency DFB Er-doped fibre laser at $\lambda=1550 \mathrm{~nm}$ was selected as the laser source. Such fibre laser source is well-suited for LFI-SNOM measurement because of its intrinsic high sensitivity to heterodyne optical feedback and its direct coupling to single-mode telecom fibre. Moreover, at $1550 \mathrm{~nm}$, the SPP propagation length $L_{p}$ was estimated around $300 \mu \mathrm{m}$ on planar gold/air interface, which is a reasonably longrange for SPP. The optical feedback loop is all-fiberized with an optical circulator used simultaneously as a beam splitter and recombiner. A fibre micro tip is scanned on the surface of the studied waveguide (scanned area up to $20 \times 20 \mu \mathrm{m}^{2}$ with $5 \mathrm{~nm}$ resolution) at constant distance above the sample using shear-force based regulation technique [5]. The collected light is frequency shifted by a pair of fiber-pigtailed acousto-optics modulator (AOMs) before being re-injected into the laser via the circulator. The frequency shift is adjusted near the relaxation oscillation frequency of the laser (typically near $700 \mathrm{kHz}$ ). Finally, the dynamical perturbation is photo-detected on the rear output of the laser and further processed via lock-in amplifier.

Figure $1 \mathrm{~b}$ illustrates as an example the electric field recorded along a gold strip. Three recorded near-field images were stitched together for increasing the scanning length along the waveguide. FDTD code taking in account the metal dielectric function is under development for comparing the experimental results with numerical simulations.
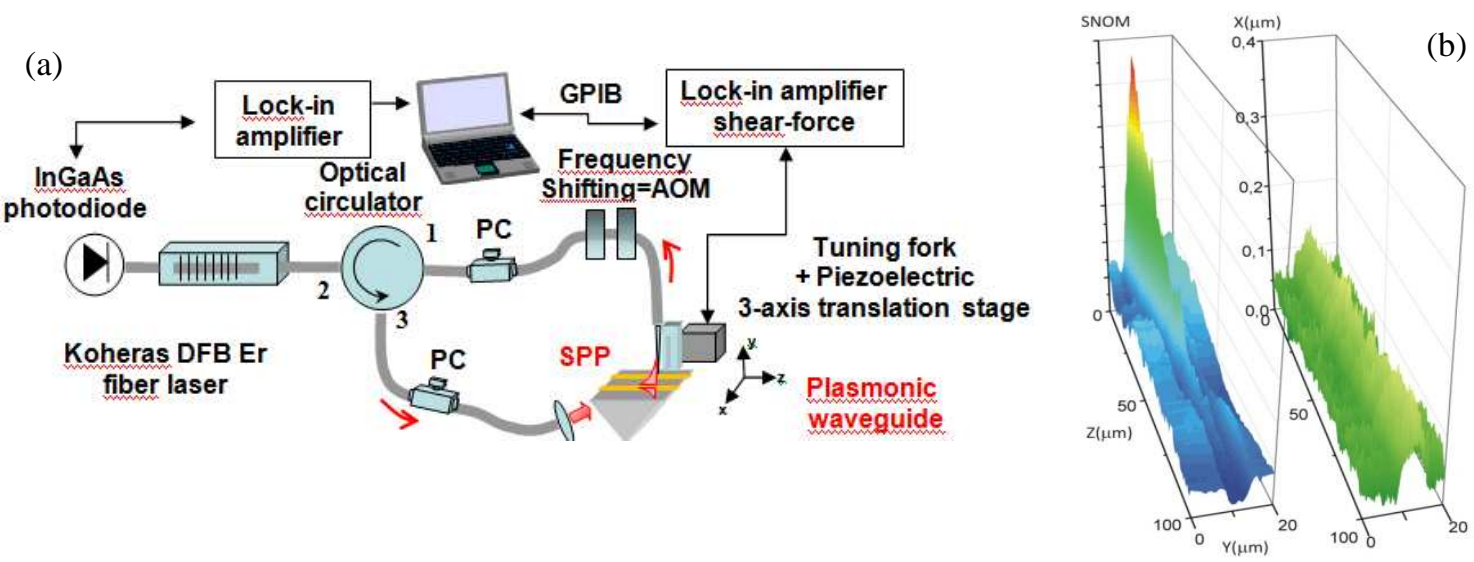

Fig. 1 (a) Experimental set-up and (b) Shear-force Topography and Near-field Optical guided mode detected using LFI-SNOM technique applied on plasmonic gold waveguides.

\section{References}

[1] H. Gilles, S. Girard, M. Laroche and A. Belarouci, "Near-field amplitude and phase measurements using heterodyne optical feedback on solid-state lasers", Optics Letters, 33 , 1 (2008).

[2] S. Blaize, B. Bérenguier, I. Stéfanon, A. Bruyant, G. Lérondel, P. Royer, O. Hugon, O. Jacquin and E. Lacot, "Phase sensitive optical near-field mapping using frequency-shifted laser optical feedback interferometry",Optics Express, 16, 11718 (2008).

[3] E. Lacot, R. Day, F. Stoeckel, "Laser optical feedback tomography“, Optics Letters, 24, 744 (1999).

[4] E. Kretschmann, H. Raether, "Radiative decay of non-radiative surface plasmons excited by light", Z. Naturforsch, 23, 2135 (1968).

[5] K. Karrai, R.D. Grober, Appl. Phys. Lett. "Piezoelectric tip-sample distance control for near field optical micro- scopes"66, 1842 (1995). 